Research Article

\title{
Chloride Ion Removal from the Wet Flue Gas Desulfurization and Denitrification Wastewater Using Friedel's Salt Precipitation Method
}

\author{
Ping Fang $\mathbb{D}^{1,2}$ Zi-jun Tang, ${ }^{1,2}$ Xiong-bo Chen $\mathbb{D}^{1},{ }^{1}$ Jian-hang Huang, ${ }^{2}$ Zhi-xiong Tang, ${ }^{2}$ \\ and Chao-ping Cen $\left(\mathbb{1}^{1}\right.$ \\ ${ }^{1}$ South China Institute of Environmental Sciences, Ministry of Environmental Protection, Guangzhou 510655, China \\ ${ }^{2}$ Guangzhou Huake Environmental Engineering Co., Ltd., Guangzhou 510655, China \\ Correspondence should be addressed to Chao-ping Cen; cenchaoping@scies.org
}

Received 12 March 2018; Accepted 29 April 2018; Published 14 May 2018

Academic Editor: Sabrina Copelli

Copyright (c) 2018 Ping Fang et al. This is an open access article distributed under the Creative Commons Attribution License, which permits unrestricted use, distribution, and reproduction in any medium, provided the original work is properly cited.

\begin{abstract}
The desulfurization and denitrification wastewater (DDW) from the wet flue gas treatment project is difficult to be treated and recycled because of high chloride ion $\left(\mathrm{Cl}^{-}\right)$concentration. $\mathrm{Cl}^{-}$can cause equipment and piping corrosion. However, there is a lack of cost-effective treatment technologies for the removal of $\mathrm{Cl}^{-}$from the DDW. In this research, the feasibility of $\mathrm{Cl}^{-}$removal from the DDW using Friedel's salt precipitation method was evaluated. Factors affecting the $\mathrm{Cl}^{-}$removal, such as $\mathrm{Ca}(\mathrm{OH})_{2}$ dosage, $\mathrm{NaAlO}_{2}$ dosage, solution's initial $\mathrm{pH}$, solution's temperature, reaction time, stirring speed, and anions $\left(\mathrm{SO}_{4}{ }^{2-}\right.$, $\mathrm{NO}_{3}{ }^{-}$, and $\left.\mathrm{F}^{-}\right)$, were investigated, and the optimal experimental conditions for $\mathrm{Cl}^{-}$removal were determined. Experimental results showed that Friedel's salt precipitation method can remove $\mathrm{Cl}^{-}$effectively and can achieve synergistic removal of $\mathrm{SO}_{4}{ }^{2-}, \mathrm{F}^{-}$, and heavy metal ions. Under the best experimental conditions, the average removal efficiencies of $\mathrm{Cl}^{-}, \mathrm{SO}_{4}{ }^{2-}, \mathrm{F}^{-}$, and heavy metal ions reach more than $85 \%, 98 \%, 94 \%$, and $99 \%$, respectively. The $\mathrm{Cl}^{-}$removal mechanism studies showed that $\mathrm{Cl}^{-}$can be removed by precipitation as $\mathrm{Ca}_{4} \mathrm{Al}_{2} \mathrm{Cl}_{2}(\mathrm{OH})_{12}$. The purified wastewater and the precipitated solid can be reused to reduce the consumption of water and alkali. Friedel's salt precipitation method is an effective control technology for the synergistic removal of $\mathrm{Cl}^{-}, \mathrm{SO}_{4}{ }^{2-}, \mathrm{F}^{-}$, and heavy metal ions and has enormous potential to be applied in the industrial wastewater treatment field.
\end{abstract}

\section{Introduction}

The wet flue gas desulfurization (WFGD) technology is one of the world's most widely used flue gas desulfurization technology due to its high desulfurization efficiency and low investment and operationg costs [1]. Meanwhile, in order to cost-effectively control $\mathrm{SO}_{2}, \mathrm{NOx}$ and other pollutants in the flue gas, scholars have developed a variety of multipollutant cooperative control technologies based on the WFGD in recent years. The main principle of the technology is through adding an oxidizing agent to the WFGD system to achieve synergistic removal of multipollutants from the flue gas. Ozone [2], chlorine dioxide [3], potassium persulfate [4], potassium permanganate [5], sodium chlorite $[6,7]$, and other oxidizing agents [8], have all been tested for multipollutants control, among which sodium chlorite $\left(\mathrm{NaClO}_{2}\right)$ has been shown to be one of the best-performing additives [7]. Industrial demonstration of the technology in which $\mathrm{NaClO}_{2}$ is used as an oxidant has been completed in China's industrial boilers and furnaces, and multipollutant removal efficiencies are satisfactory. However, there are still some deficiencies in the technology that need to be improved. One of the more prominent problems is the corrosion of equipment and piping caused by $\mathrm{Cl}^{-}$accumulation. The concentration of $\mathrm{Cl}^{-}$in the absorption solution is generally $1000-3000 \mathrm{mg} / \mathrm{L}$. The maximum can be more than $10000 \mathrm{mg} / \mathrm{L} . \mathrm{Cl}^{-}$can promote corrosion through destroying the passive film of metal and accelerating the growth of pitting corrosion [9]. Furthermore, most of the corrosion and scale inhibitors cannot really inhibit the $\mathrm{Cl}^{-}$corrosion [10]. Therefore, part 
of absorption solution must be discharged to regulate the concentration of $\mathrm{Cl}^{-}$and other impurities in the solution and to form the wet flue gas DDW. Furthermore, the WFGD absorption solution, industrial cooling water, and other industrial wastewater also have the $\mathrm{Cl}^{-}$accumulation problem, which leads to metal corrosion. However, the chemical precipitation method, which is usually used to treat desulfurization wastewater (DW), is difficult to remove $\mathrm{Cl}^{-}$. As a result, the chlorine-containing wastewater cannot be directly discharged or reused [11]. Hence, in order to avoid $\mathrm{Cl}^{-}$corrosion and promote DDW recycling, it is necessary to develop a cost-effective $\mathrm{Cl}^{-}$removal technology.

Currently, various $\mathrm{Cl}^{-}$removal technologies have been developed, mainly including evaporation crystallization [12], electrochemical method [13, 14], adsorption $[15,16]$, ion exchange [17, 18], and reverse osmosis [19]. However, these methods are complex and have high operating costs, and most of them are suitable for the treatment wastewater of a low $\mathrm{Cl}^{-}$ concentration. Chemical precipitation methods, such as silver salt precipitation [20], copper slag precipitation [21], and Friedel's salt precipitation (ultra-high lime with aluminum process, UHLA) [22], are all very suitable for the treatment of wastewater with high $\mathrm{Cl}^{-}$concentration. Among them, Friedel's salt precipitation method is considered to be a costeffective $\mathrm{Cl}^{-}$removal technology. The fundamental of the UHLA method is through adding an excess of calcium salt and aluminum salt to the chlorine-containing solution, and the calcium and aluminum ions react with chloride ion to form a precipitate of $\mathrm{Ca}_{4} \mathrm{Al}_{2} \mathrm{Cl}_{2}(\mathrm{OH})_{12}$ which is called Friedel's salt at a certain reaction temperature and stirring speed, and finally the high efficient removal of chloride ion is achieved. AbdelWahab et al. $[10,22]$ evaluated $\mathrm{Cl}^{-}$removal from recycled cooling water using the UHLA process and investigated the effect of aluminum dosage and lime dosage on $\mathrm{Cl}^{-}$removal at room temperature. Experimental results showed that the UHLA process can effectively remove $\mathrm{Cl}^{-}$by precipitation as calcium chloroaluminate $\left[\mathrm{Ca}_{4} \mathrm{Al}_{2} \mathrm{Cl}_{2}(\mathrm{OH})_{12}\right]$. $\mathrm{Cl}^{-}$removal was barely affected by the lime dosage, but significantly affected by the aluminum dosage. The optimal $\mathrm{Ca} / \mathrm{Al}$ ratio to achieve maximum $\mathrm{Cl}^{-}$removal was approximately 2.5 .

However, these studies focused on the $\mathrm{Cl}^{-}$removal from the circulating cooling water and did not consider the effect of coexistent anions, such as $\mathrm{SO}_{4}{ }^{2-}, \mathrm{NO}_{3}{ }^{-}$, and $\mathrm{F}^{-}$, on the $\mathrm{Cl}^{-}$ removal. Meanwhile, there is little information about the effect of process parameters, such as the solution's initial $\mathrm{pH}$, reaction temperature, and reaction time on the $\mathrm{Cl}^{-}$removal. The composition of the ions in the circulating cooling water is relatively simple, and the concentration of different kinds of ions is also lower compared to that of the DDW and the DW, but nowadays little information on the $\mathrm{Cl}^{-}$removal from the DDW or the DW using Friedel's salt precipitation method can be found in the literatures. Therefore, the research aims to evaluate the feasibility of the $\mathrm{Cl}^{-}$removal from the wet flue gas DDW using Friedel's salt precipitation method. A series of experiments to evaluate the influence of different factors on $\mathrm{Cl}^{-}$removal were carried out, and the $\mathrm{Cl}^{-}$removal mechanism by this process was hypothesized. In addition, removal of $\mathrm{Cl}^{-}$and other ions in the actual DDW using Friedel's salt precipitation method was also studied.

\section{Experimental Setup}

2.1. Materials. $\mathrm{NaAlO}_{2}, \mathrm{Ca}(\mathrm{OH})_{2}, \mathrm{Na}_{2} \mathrm{SO}_{4}, \mathrm{NaOH}, \mathrm{NaF}$, $\mathrm{NaCl}, \mathrm{KNO}_{3}$, and $\mathrm{HNO}_{3}$ were analytical grade, and directly used without purification. The authors tested $\mathrm{Cl}^{-}$concentration in the actual DDW and found that the $\mathrm{Cl}^{-}$concentration in the DDW was about $1000-3000 \mathrm{mg} / \mathrm{L}$. So chloride-rich simulated wastewater used in this study was prepared by dissolving anhydrous $\mathrm{NaCl}$ in deionized water to get initial $\mathrm{Cl}^{-}$concentration of $2000 \mathrm{mg} / \mathrm{L}$. The solution's initial $\mathrm{pH}$ was adjusted using $\mathrm{HNO}_{3}(0.1 \mathrm{~mol} / \mathrm{L})$ and $\mathrm{NaOH}$ $(0.1 \mathrm{~mol} / \mathrm{L})$. The actual DDW was obtained from a ceramic production enterprise located in Guangdong province, China.

2.2. Analytical Methods. The solution's $\mathrm{pH}$ was measured with an MP511 pH detector (Shanghai Precision Instruments Co., Ltd.). Concentrations of $\mathrm{NO}_{3}{ }^{-}, \mathrm{F}^{-}, \mathrm{SO}_{4}{ }^{2-}$, and $\mathrm{Cl}^{-}$were measured with an ion chromatography system (Metrohm 883, Switzerland), and concentrations of heavy metal ions such as $\mathrm{Ni}^{2+}, \mathrm{Pb}^{2+}$, and $\mathrm{Mn}^{2+}$ were determined with an inductively coupled plasma emission spectrometer (ICP-AES 710, Agilent technologies). The precipitated solids were collected by filtering. The separated solids were then dried at room temperature. X-ray diffraction (XRD) was performed on the solids using an X-ray diffractometer (XRD-6000, Shimadzu, Japan).

2.3. Removal of Chloride Ions. Experiments were carried out on a six-league electric blender (ZR4-6, China). The experimental steps of Friedel's salt precipitation method are as follows: the first step was conducted by adding a certain amount of $\mathrm{Ca}(\mathrm{OH})_{2}$ and $\mathrm{NaAlO}_{2}$ to the $\mathrm{NaCl}$ solution $(2000 \mathrm{mg} / \mathrm{L})$ with a volume of $1 \mathrm{~L}$ at the specified reaction temperature; then stirring for a certain time, at last samples were taken and filtered under vacuum through a $0.45 \mu \mathrm{m}$ microporous membrane filter. The filtrate was analyzed for $\mathrm{Cl}^{-}$and other ions using related equipments, and finally the removal efficiencies of $\mathrm{Cl}^{-}$and other ions were calculated by the following equation. The solid phases formed in precipitation experiments were identified by XRD spectroscopy.

$$
\eta=\frac{C_{0}-C_{\mathrm{t}}}{C_{0}} \times 100
$$

where $\eta$ is the $\mathrm{Cl}^{-}$or other ions removal efficiencies; and $C_{0}$ and $C_{\mathrm{t}}$ are the initial and final $\mathrm{Cl}^{-}$or other ions concentrations of solutions $(\mathrm{mg} / \mathrm{L})$, respectively.

According to the characteristics of ion composition of actual DDW, the literatures [10,20,22,23] and an analysis of main factors influencing $\mathrm{Cl}^{-}$removal, a series of experiments were conducted to evaluate $\mathrm{Cl}^{-}$removal from DDW using Friedel's salt precipitation method, and the optimal experimental conditions for $\mathrm{Cl}^{-}$removal were determined by using single factor test. In addition, the removal experiments of chloride ions from a ceramic enterprise wastewater were carried out under the best experimental conditions. The experimental conditions of the individual experiments are shown in Table 1. 
TABLE 1: Experimental conditions of the individual experiments.

\begin{tabular}{|c|c|c|}
\hline Number & Experiment & Experimental conditions \\
\hline 1 & The effect of $\mathrm{NaAlO}_{2}$ dosage & $\begin{array}{c}V_{\text {solution }}=1 \mathrm{~L},\left[\mathrm{Cl}^{-}\right]=2000 \mathrm{mg} / \mathrm{L}, T_{\text {reaction }}=25^{\circ} \mathrm{C} \\
v_{\text {stirring }}=400 \mathrm{r} / \mathrm{min}, t=30 \mathrm{~min}, \text { initial } \mathrm{pH}=7.0 .\end{array}$ \\
\hline 2 & The effect of $\mathrm{Ca}(\mathrm{OH})_{2}$ dosage & $\begin{array}{l}V_{\text {solution }}=1 \mathrm{~L},\left[\mathrm{Cl}^{-}\right]=2000 \mathrm{mg} / \mathrm{L}, T_{\text {reaction }}=25^{\circ} \mathrm{C} \\
v_{\text {stirring }}=400 \mathrm{r} / \mathrm{min}, t=30 \mathrm{~min}, \text { initial } \mathrm{pH}=7.0\end{array}$ \\
\hline 3 & The effect of the solution's initial $\mathrm{pH}$ & $\begin{array}{c}V_{\text {solution }}=1 \mathrm{~L},\left[\mathrm{Cl}^{-}\right]=2000 \mathrm{mg} / \mathrm{L}, \mathrm{Ca} / \mathrm{Al} / \mathrm{Cl} \mathrm{molar} \\
\text { ratio }=6: 3: 1, T_{\text {reaction }}=25^{\circ} \mathrm{C}, v_{\text {stirring }}=400 \mathrm{r} / \mathrm{min} \\
t=30 \mathrm{~min}\end{array}$ \\
\hline 4 & The effect of the solution's temperature & $\begin{array}{c}V_{\text {solution }}=1 \mathrm{~L},\left[\mathrm{Cl}^{-}\right]=2000 \mathrm{mg} / \mathrm{L}, \mathrm{Ca} / \mathrm{Al} / \mathrm{Cl} \text { molar } \\
\text { ratio }=6: 3: 1, v_{\text {stirring }}=400 \mathrm{r} / \mathrm{min}, t=30 \mathrm{~min} \text {, initial } \\
\mathrm{pH}=7.0 .\end{array}$ \\
\hline 5 & The effect of reaction time & $\begin{array}{c}V_{\text {solution }}=1 \mathrm{~L},\left[\mathrm{Cl}^{-}\right]=2000 \mathrm{mg} / \mathrm{L}, \mathrm{Ca} / \mathrm{Al} / \mathrm{Cl} \mathrm{molar} \\
\text { ratio }=6: 3: 1, T_{\text {reaction }}=25^{\circ} \mathrm{C}, v_{\text {stirring }}=400 \mathrm{r} / \mathrm{min} \\
\text { initial } \mathrm{pH}=7.0\end{array}$ \\
\hline 6 & The effect of stirring speed & $\begin{array}{c}V_{\text {solution }}=1 \mathrm{~L},\left[\mathrm{Cl}^{-}\right]=2000 \mathrm{mg} / \mathrm{L}, \mathrm{Ca} / \mathrm{Al} / \mathrm{Cl} \text { molar } \\
\text { ratio }=6: 3: 1, T_{\text {reaction }}=25^{\circ} \mathrm{C}, t=30 \mathrm{~min} \text {, initial } \\
\mathrm{pH}=7.0\end{array}$ \\
\hline 7 & The effect of $\mathrm{SO}_{4}{ }^{2-}$ concentration & $\begin{array}{c}V_{\text {solution }}=1 \mathrm{~L},\left[\mathrm{Cl}^{-}\right]=2000 \mathrm{mg} / \mathrm{L}, \mathrm{Ca} / \mathrm{Al} / \mathrm{Cl} \text { molar } \\
\text { ratio }=6: 3: 1, T_{\text {reaction }}=25^{\circ} \mathrm{C}, v_{\text {stirring }}=400 \mathrm{r} / \mathrm{min} \\
t=30 \mathrm{~min} \text {, initial } \mathrm{pH}=7.0\end{array}$ \\
\hline 8 & The effect of $\mathrm{F}^{-}$concentration & $\begin{array}{c}V_{\text {solution }}=1 \mathrm{~L},\left[\mathrm{Cl}^{-}\right]=2000 \mathrm{mg} / \mathrm{L}, \mathrm{Ca} / \mathrm{Al} / \mathrm{Cl} \mathrm{molar} \\
\text { ratio }=6: 3: 1, T_{\text {reaction }}=25^{\circ} \mathrm{C}, v_{\text {stirring }}=400 \mathrm{r} / \mathrm{min} \\
t=30 \mathrm{~min} \text {, initial } \mathrm{pH}=7.0\end{array}$ \\
\hline 9 & The effect of $\mathrm{NO}_{3}{ }^{-}$concentration & $\begin{array}{c}V_{\text {solution }}=1 \mathrm{~L},\left[\mathrm{Cl}^{-}\right]=2000 \mathrm{mg} / \mathrm{L}, \mathrm{Ca} / \mathrm{Al} / \mathrm{Cl} \mathrm{molar} \\
\text { ratio }=6: 3: 1, T_{\text {reaction }}=25^{\circ} \mathrm{C}, v_{\text {stirring }}=400 \mathrm{r} / \mathrm{min} \\
t=30 \mathrm{~min} \text {, initial } \mathrm{pH}=7.0\end{array}$ \\
\hline 10 & The effect of precipitated solid reuse & $\begin{array}{c}V_{\text {solution }}=1 \mathrm{~L},\left[\mathrm{Cl}^{-}\right]=2000 \mathrm{mg} / \mathrm{L}, \mathrm{Ca} / \mathrm{Al} / \mathrm{Cl} \mathrm{molar} \\
\text { ratio }=6: 3: 1, T_{\text {reaction }}=25^{\circ} \mathrm{C}, v_{\text {stirring }}=400 \mathrm{r} / \mathrm{min} \\
t=30 \mathrm{~min} \text {, initial } \mathrm{pH}=7.0\end{array}$ \\
\hline 11 & $\begin{array}{l}\text { Removal of chloride ion and other ions in actual } \\
\text { DDW }\end{array}$ & $\begin{array}{l}\text { Two-stage Freund's salt precipitation method: }(1) \\
\text { First stage mainly removed } \mathrm{SO}_{4}{ }^{2-}, V_{\text {solution }}=1 \mathrm{~L} \text {, } \\
\mathrm{Ca} / \mathrm{Al} / \mathrm{S} \text { molar ratio }=4: 1: 1, T_{\text {reaction }}=25^{\circ} \mathrm{C} \text {, } \\
v_{\text {stirring }}=400 \mathrm{r} / \mathrm{min}, t=30 \mathrm{~min} .(2) \mathrm{Second} \text { stage } \\
\text { mainly removed } \mathrm{Cl}^{-}, V_{\text {solution }}=1 \mathrm{~L}, \mathrm{Ca} / \mathrm{Al} / \mathrm{Cl} \text { molar } \\
\text { ratio }=6: 3: 1, T_{\text {reaction }}=25^{\circ} \mathrm{C}, v_{\text {stirring }}=400 \mathrm{r} / \mathrm{min} \text {, } \\
\qquad t=30 \mathrm{~min} .\end{array}$ \\
\hline
\end{tabular}

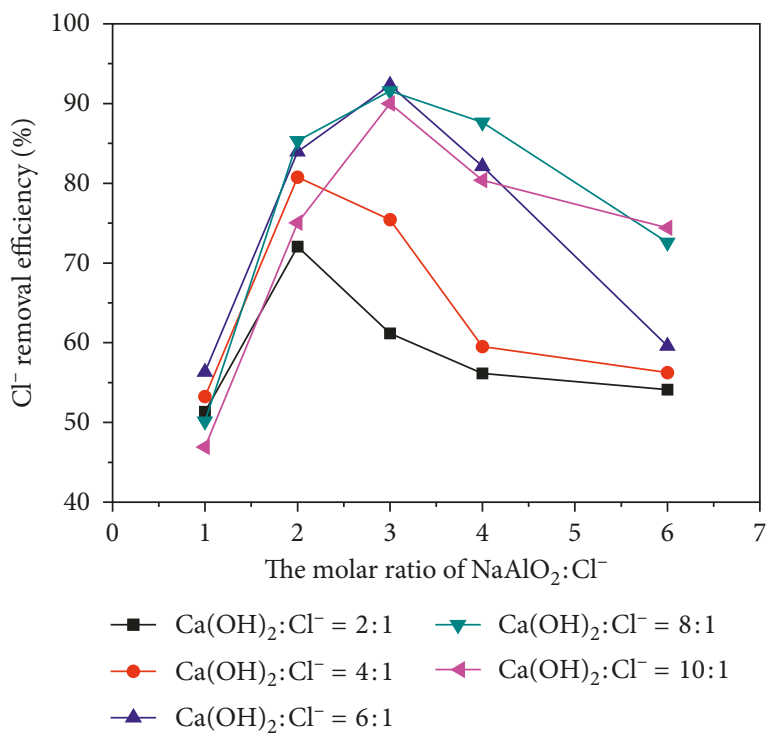

Figure 1: The effect of $\mathrm{NaAlO}_{2}$ dosage.

\section{Results and Discussion}

3.1. Effect of $\mathrm{NaAlO}_{2}$ Dosage and $\mathrm{Ca}(\mathrm{OH})_{2}$ Dosage. It was reported that $\mathrm{Cl}^{-}$removal was primarily controlled by the formation of $\mathrm{Ca}_{4} \mathrm{Al}_{2} \mathrm{Cl}_{2}(\mathrm{OH})_{12}$ [22]. So $\mathrm{NaAlO}_{2}$ dosage and $\mathrm{Ca}(\mathrm{OH})_{2}$ dosage have a significant effect on $\mathrm{Cl}^{-}$removal. As shown in Figure 1, good $\mathrm{Cl}^{-}$removal $(>85 \%)$ was observed at reasonable ranges of $\mathrm{NaAlO}_{2}$ dosage and $\mathrm{Ca}(\mathrm{OH})_{2}$ dosage. It was found that the $\mathrm{Cl}^{-}$removal increased upon increasing the molar ratios of $\mathrm{NaAlO}_{2}$ to $\mathrm{Cl}^{-}(\mathrm{Al} / \mathrm{Cl})$ at first, then decreased with the $\mathrm{Al} / \mathrm{Cl}$ increase when the molar ratio of $\mathrm{Ca}(\mathrm{OH})_{2}$ to $\mathrm{Cl}^{-}(\mathrm{Ca} / \mathrm{Cl})$ was constant. For example, when the $\mathrm{Ca} / \mathrm{Cl}$ was constant at $6: 1$, the $\mathrm{Cl}^{-}$removal sharply increased from $56.3 \%$ to $91.6 \%$ when the $\mathrm{Al} / \mathrm{Cl}$ varied from $1: 1$ to $3: 1$, then $\mathrm{Cl}^{-}$removal decreased from $91.6 \%$ to $59.6 \%$ with an increase of $\mathrm{Al} / \mathrm{Cl}$ between $3: 1$ and $6: 1$. Higher $\mathrm{NaAlO}_{2}$ dosage is not conducive to the $\mathrm{Cl}^{-}$removal. Addition of excess $\mathrm{NaAlO}_{2}$ results in increasing $\mathrm{Al}(\mathrm{OH})_{4}{ }^{-}$and $\mathrm{OH}^{-}$ions ((2) and (3)) in the solution, and the increases of $\mathrm{OH}^{-}$and $\mathrm{Al}(\mathrm{OH})_{4}{ }^{-}$ions result in substitution of $\mathrm{Cl}^{-}$with $\mathrm{OH}^{-}$and $\mathrm{Al}(\mathrm{OH})_{4}^{-}((6)$ and $(7))$ in the solid solution formation, thus increasing the fraction of $\mathrm{Ca}_{3} \mathrm{Al}_{2}(\mathrm{OH})_{12}$ and 


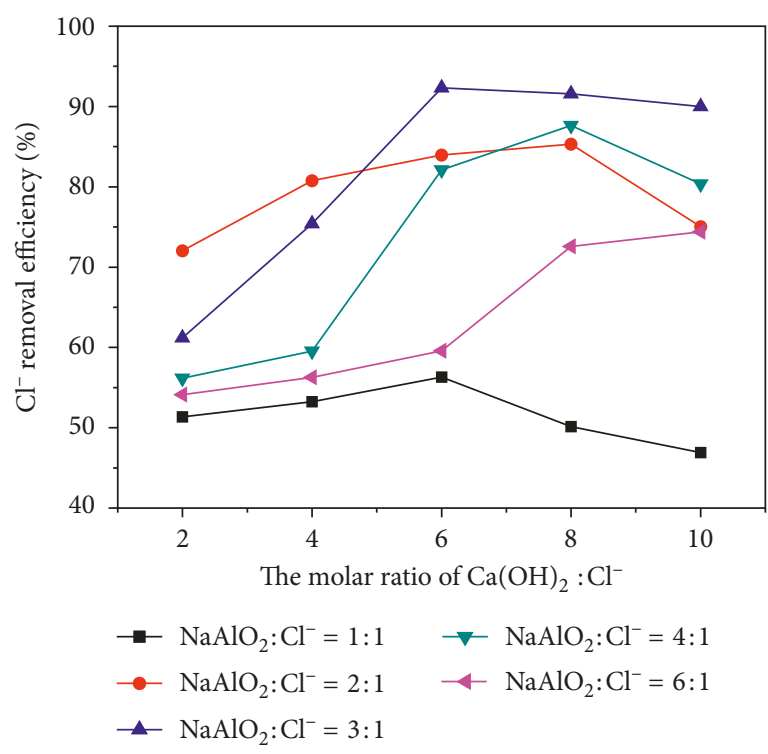

Figure 2: The effect of $\mathrm{Ca}(\mathrm{OH})_{2}$ dosage.

decreasing the fractions of $\mathrm{Ca}_{4} \mathrm{Al}_{2} \mathrm{Cl}_{2}(\mathrm{OH})_{12}$ and $\mathrm{Ca}_{4} \mathrm{Al}_{2}(\mathrm{OH})_{14}$ in the solid solution. So, the results show that there is an optimum range of $\mathrm{Al} / \mathrm{Cl}$ of $2-4: 1$.

Figure 2 shows the effect of $\mathrm{Ca}(\mathrm{OH})_{2}$ dosage on $\mathrm{Cl}^{-}$removal. When the $\mathrm{Al} / \mathrm{Cl}$ was $1: 1$, the $\mathrm{Ca}(\mathrm{OH})_{2}$ dosage had little effect on $\mathrm{Cl}^{-}$removal. However, the $\mathrm{Cl}^{-}$removal was greatly affected by the $\mathrm{Ca}(\mathrm{OH})_{2}$ dosage when the $\mathrm{Al} / \mathrm{Cl}$ was more than $1: 1$. As depicted in Figure 2, when the $\mathrm{Al} / \mathrm{Cl}$ was constant, $\mathrm{Cl}^{-}$ removal increased rapidly as the $\mathrm{Ca} / \mathrm{Cl}$ increased at first, then decreased with the increase of $\mathrm{Ca} / \mathrm{Cl}$. This is because the $\mathrm{Ca}$ $(\mathrm{OH})_{2}$ solubility is low, $\mathrm{Ca}^{2+}$ concentration in the solution increases with the increasing of $\mathrm{Ca}(\mathrm{OH})_{2}$ dosage, meanwhile $\mathrm{OH}^{-}$concentration also increases in the solution. The increasing of $\mathrm{Ca}^{2+}$ concentration leads to increased $\mathrm{Cl}^{-}$removal; however, the increase of $\mathrm{OH}^{-}$concentration is not conducive to the $\mathrm{Cl}^{-}$removal because the $\mathrm{Cl}^{-}$in the $\mathrm{Ca}_{4} \mathrm{Al}_{2} \mathrm{Cl}_{2}(\mathrm{OH})_{12}$ can be replaced by $\mathrm{OH}^{-}$to form the $\mathrm{Ca}_{4} \mathrm{Al}_{2}(\mathrm{OH})_{14}$ (6) under the higher $\mathrm{OH}^{-}$concentration condition. So, the results show that there is an optimum range of $\mathrm{Ca} / \mathrm{Cl}$ of $6-8: 1$.

In order to further determine the effect of the dosage of chemical reagents on $\mathrm{Cl}^{-}$removal and to determine the reaction product type, XRD was used to examine the crystalline phases of the precipitated solids produced under different conditions, and the results are shown in Figure 3.

Examination of the samples indicates the presence of mixed phases, the major crystalline phases are $\mathrm{Ca}_{4} \mathrm{Al}_{2} \mathrm{Cl}_{2}(\mathrm{OH})_{12}$ (ICDD PDF card \# 35-0105, $2 \theta=11.4^{\circ}, 22.8^{\circ}, 23.6^{\circ}, 31.1^{\circ}, 35.6^{\circ}$, and $\left.42.7^{\circ}\right), \mathrm{Ca}_{4} \mathrm{Al}_{2}(\mathrm{OH})_{14}$ (ICDD PDF card \# 33-0255, $2 \theta=11.4^{\circ}, 31.1^{\circ}, 38.9^{\circ}$, and $\left.64.5^{\circ}\right), \mathrm{Ca}_{3} \mathrm{Al}_{2}(\mathrm{OH})_{12}$ (ICDD PDF card \# 24-0217, $2 \theta=17.4^{\circ}, 20.0^{\circ}, 26.7^{\circ}, 28.5^{\circ}, 31.9^{\circ}, 36.5^{\circ}, 39.3^{\circ}$, $44.5^{\circ}, 52.6^{\circ}, 54.6^{\circ}$, and $\left.66.4^{\circ}\right)$, and $\mathrm{Ca}(\mathrm{OH})_{2}$ (ICDD PDF card \# 04-0733, $2 \theta=18.3^{\circ}, 34.3^{\circ}, 47.4^{\circ}$, and $51.0^{\circ}$ ). As shown in Figure 3(a), the intensities of characteristic diffraction peaks of $\mathrm{Ca}_{4} \mathrm{Al}_{2} \mathrm{Cl}_{2}(\mathrm{OH})_{12}$ and $\mathrm{Ca}_{4} \mathrm{Al}_{2}(\mathrm{OH})_{14}$ all increased with the increasing $\mathrm{Ca}(\mathrm{OH})_{2}$ dosage at first, then decreased slowly with the increase of $\mathrm{Ca}(\mathrm{OH})_{2}$ dosage. On the contrary, the intensities of characteristic diffraction peaks of $\mathrm{Ca}_{3} \mathrm{Al}_{2}(\mathrm{OH})_{12}$ decreased as

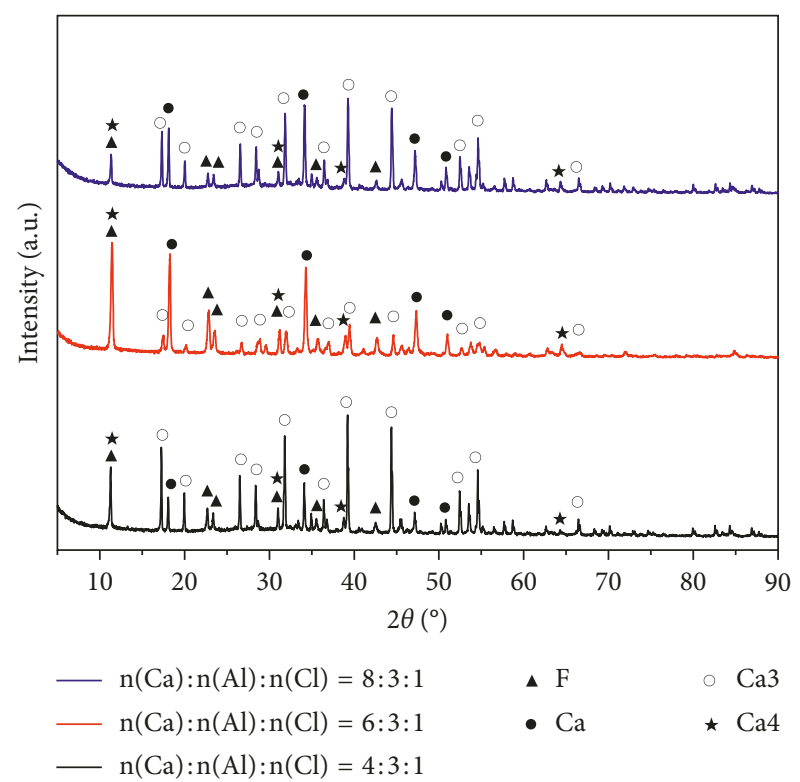

(a)

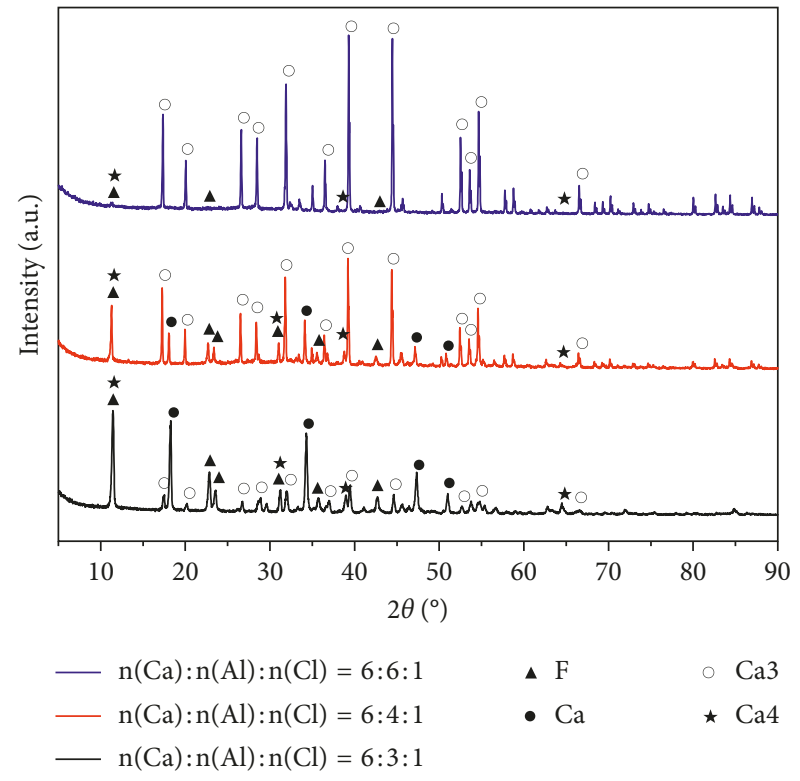

(b)

FIGURE 3: XRD patterns of precipitated solids: (a) different $\mathrm{Ca}(\mathrm{OH})_{2}$ dosage; (b) different $\mathrm{NaAlO}_{2}$ dosage. $\mathrm{F}\left(\mathrm{Ca}_{4} \mathrm{Al}_{2} \mathrm{Cl}_{2}(\mathrm{OH})_{12}\right)$, Ca3 $\left(\mathrm{Ca}_{3} \mathrm{Al}_{2}(\mathrm{OH})_{12}\right), \mathrm{Ca} 4\left(\mathrm{Ca}_{4} \mathrm{Al}_{2}(\mathrm{OH})_{14}\right), \mathrm{Ca}\left(\mathrm{Ca}(\mathrm{OH})_{2}\right)$.

the $\mathrm{Ca}(\mathrm{OH})_{2}$ dosage increased at first, then increased with the increase of $\mathrm{Ca}(\mathrm{OH})_{2}$ dosage. This may be attributed to the increase in concentration of $\mathrm{Ca}^{2+}$ in solution with $\mathrm{Ca}(\mathrm{OH})_{2}$ dosage increase, thus promoting the $\mathrm{Ca}_{4} \mathrm{Al}_{2} \mathrm{Cl}_{2}(\mathrm{OH})_{12}$ and $\mathrm{Ca}_{4} \mathrm{Al}_{2}(\mathrm{OH})_{14}$ generation ((4), (5) and (6)). However, higher $\mathrm{Ca}(\mathrm{OH})_{2}$ dosage contributes to the $\mathrm{OH}^{-}$concentration increase in solution and promote the progress of the reactions $((7)$ and (8)), resulting in an increase of $\mathrm{Ca}_{3} \mathrm{Al}_{2}(\mathrm{OH})_{12}$ and decrease of $\mathrm{Ca}_{4} \mathrm{Al}_{2} \mathrm{Cl}_{2}(\mathrm{OH})_{12}$ and $\mathrm{Ca}_{4} \mathrm{Al}_{2}(\mathrm{OH})_{14}$ in the solids. In addition, the intensities of characteristic diffraction peaks of $\mathrm{Ca}(\mathrm{OH})_{2}$ increased with the increasing $\mathrm{Ca}(\mathrm{OH})_{2}$ dosage. The results of 


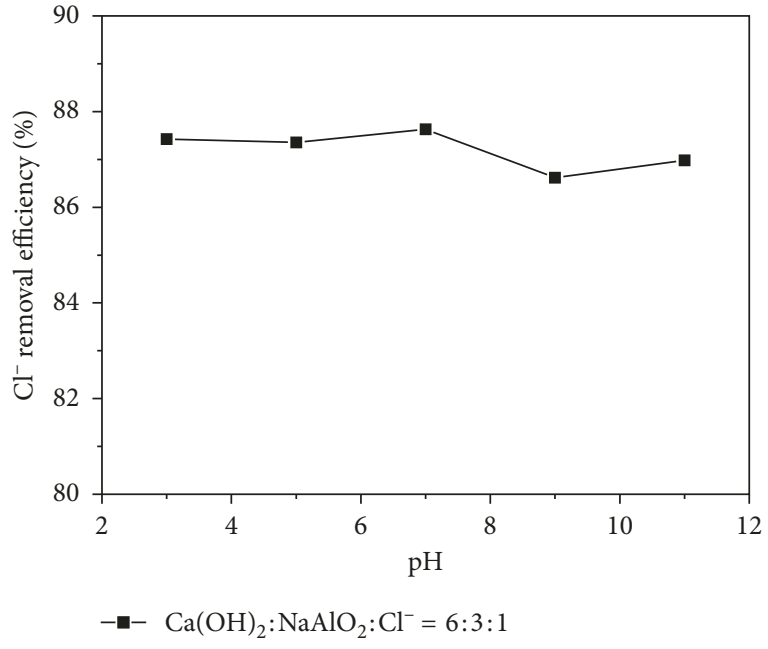

FIgURE 4: The effect of the solution's initial $\mathrm{pH}$.

XRD test are in good agreement with the results of $\mathrm{Cl}^{-}$removal (Figure 1).

Figure 3(b) shows that additions of $\mathrm{NaAlO}_{2}$ had significant influences on the distribution of solids in the solid solution. When the $\mathrm{Ca} / \mathrm{Cl}$ was constant at $6: 1$ and the $\mathrm{Al} / \mathrm{Cl}$ was more than $3: 1$, the intensities of characteristic diffraction peaks of $\mathrm{Ca}_{4} \mathrm{Al}_{2} \mathrm{Cl}_{2}(\mathrm{OH})_{12}, \mathrm{Ca}_{4} \mathrm{Al}_{2}(\mathrm{OH})_{14}$, and $\mathrm{Ca}(\mathrm{OH})_{2}$ all decreased rapidly with the increasing $\mathrm{NaAlO}_{2}$ dosage; however, the intensities of characteristic diffraction peaks of $\mathrm{Ca}_{3} \mathrm{Al}_{2}(\mathrm{OH})_{12}$ increased rapidly as the $\mathrm{NaAlO}_{2}$ dosage increased. Especially,

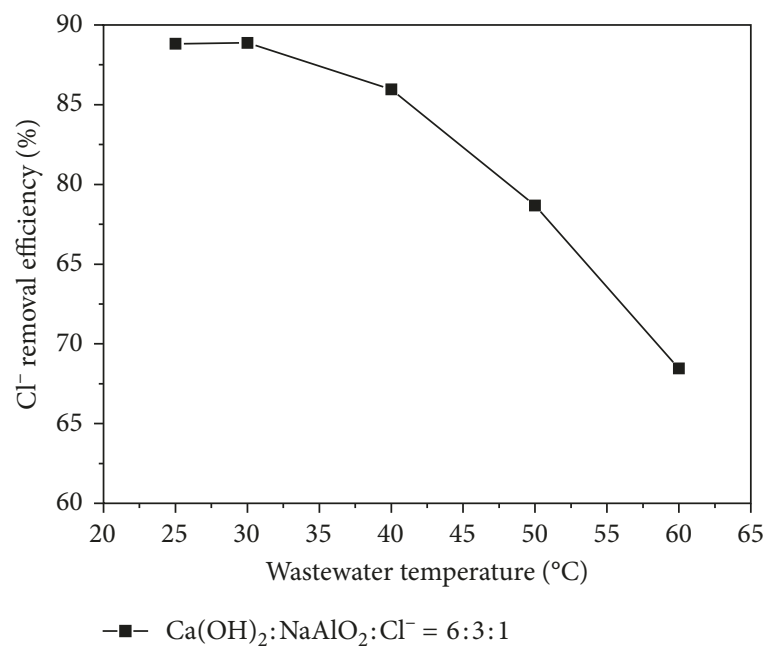

Figure 5: The effect of the solution's temperature.

examination of the sample $(n(\mathrm{Ca}): n(\mathrm{Al}): n(\mathrm{Cl})=6: 6: 1)$ indicated that phases related to crystalline $\mathrm{Ca}(\mathrm{OH})_{2}$ were not observed, suggesting that almost no $\mathrm{Ca}(\mathrm{OH})_{2}$ was contained in the solids. The results of XRD test are in good agreement with the results of $\mathrm{Cl}^{-}$removal (Figure 2).

Based on the experimental results, composition of the solids, and the literatures $[10,20,22,23], \mathrm{Cl}^{-}$removal reaction equations and the interactions among the solids during formation of the solid solution can be described by using the following chemical equilibrium reactions:

$$
\begin{aligned}
\mathrm{NaAlO}_{2}+2 \mathrm{H}_{2} \mathrm{O} & =\mathrm{NaOH}+\mathrm{Al}(\mathrm{OH})_{3} \\
\mathrm{Al}(\mathrm{OH})_{3}+\mathrm{OH}^{-} & =\mathrm{Al}(\mathrm{OH})_{4}^{-} \\
4 \mathrm{Ca}(\mathrm{OH})_{2}+2 \mathrm{Al}(\mathrm{OH})_{3} & =\mathrm{Ca}_{4} \mathrm{Al}_{2}(\mathrm{OH})_{14} \\
4 \mathrm{Ca}(\mathrm{OH})_{2}+2 \mathrm{Al}(\mathrm{OH})_{3}+2 \mathrm{Cl}^{-} & =\mathrm{Ca}_{4} \mathrm{Al}_{2}(\mathrm{OH})_{12} \mathrm{Cl}_{2}+2 \mathrm{OH}^{-} \\
\mathrm{Ca}_{4} \mathrm{Al}_{2}(\mathrm{OH})_{12} \mathrm{Cl}_{2}+2 \mathrm{OH}^{-} & =\mathrm{Ca}_{4} \mathrm{Al}_{2}(\mathrm{OH})_{14}+2 \mathrm{Cl}^{-} \\
3 \mathrm{Ca}_{4} \mathrm{Al}_{2}(\mathrm{OH})_{12} \mathrm{Cl}_{2}+2 \mathrm{Al}(\mathrm{OH})_{4}^{-}+4 \mathrm{OH}{ }^{-} & =4 \mathrm{Ca}_{3} \mathrm{Al}_{2}(\mathrm{OH})_{12}+6 \mathrm{Cl}^{-} \\
3 \mathrm{Ca}_{4} \mathrm{Al}_{2}(\mathrm{OH})_{14}+2 \mathrm{Al}(\mathrm{OH})_{4}^{-} & =4 \mathrm{Ca}_{3} \mathrm{Al}_{2}(\mathrm{OH})_{12}+2 \mathrm{OH}^{-}
\end{aligned}
$$

Considering the $\mathrm{Cl}^{-}$removal and economic costs, in the next series of experiments, the molar ratio of $\mathrm{Ca}(\mathrm{OH})_{2}$ to $\mathrm{NaAlO}_{2}$ to $\mathrm{Cl}^{-}$were constant at $6: 3: 1$.

3.2. Effect of the Initial $p H$. The effect of the solution's initial $\mathrm{pH}$ ranging from 3.0 to 11.0 on $\mathrm{Cl}^{-}$removal has been studied. Figure 4 shows that the initial $\mathrm{pH}$ of solution had negligible effects on the $\mathrm{Cl}^{-}$removal, and the average removal efficiencies of $\mathrm{Cl}^{-}$remained at around $87 \%$ when the solution's initial $\mathrm{pH}$ changed from 3.0 to 11.0 . The reason is that the addition of
$\mathrm{Ca}(\mathrm{OH})_{2}$ was excessive in this series of experiments, and regardless of whether the solution was acidic or alkaline, the solution's $\mathrm{pH}$ all increased to about 13.0 after adding excessive $\mathrm{Ca}(\mathrm{OH})_{2}$. The initial $\mathrm{pH}$ of solution has little effect on $\mathrm{Cl}^{-}$ removal, so the effect of wastewater $\mathrm{pH}$ need not be considered when using the method to control the $\mathrm{Cl}^{-}$in practical engineering applications.

3.3. Effect of Solution's Temperature. Figure 5 presents the effect of the solution's temperature on $\mathrm{Cl}^{-}$removal. The $\mathrm{Cl}^{-}$ 


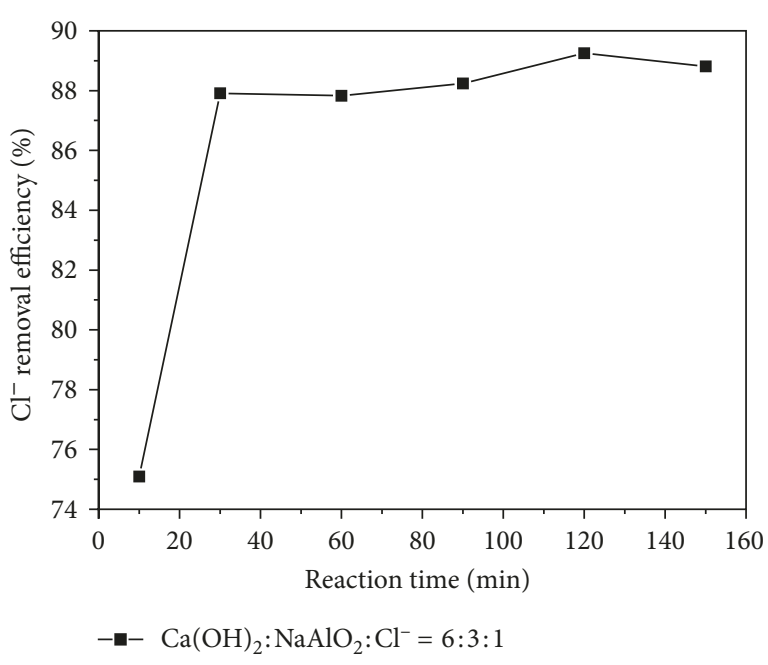

FIgURE 6: The effect of reaction time.

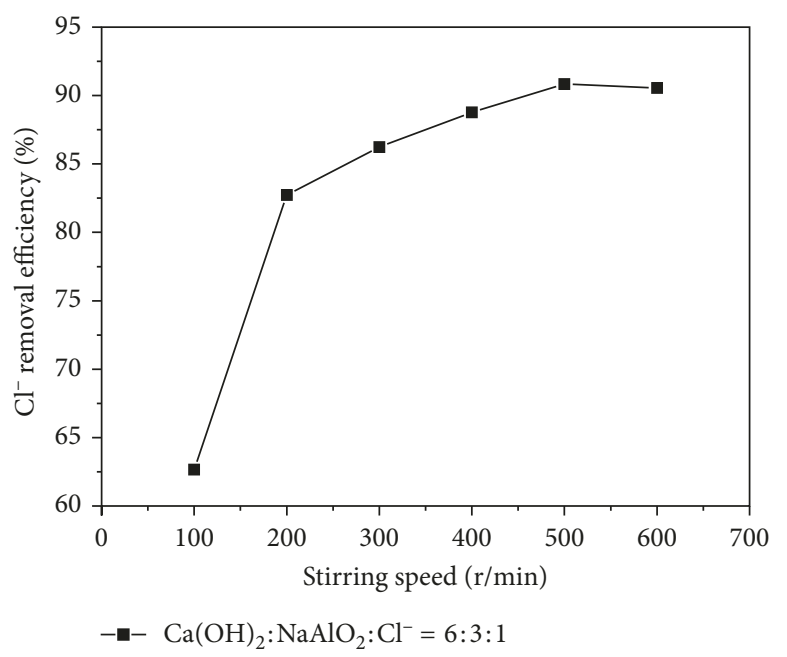

Figure 7: The effect of stirring speed.

removal decreased with the increasing temperature of the solution. $\mathrm{Cl}^{-}$removal efficiencies were $88.8 \%, 88.9 \%, 86.0 \%$, $78.7 \%$, and $68.5 \%$ when the solution's temperatures were 25 , $30,40,50$, and $60^{\circ} \mathrm{C}$, respectively. As Figure 5 illustrates, $\mathrm{Cl}^{-}$ removal decreased slowly with the solution's increasing temperature when the solution's temperature was less than $40^{\circ} \mathrm{C}$, but when the solution's temperature was more than $40^{\circ} \mathrm{C}$, the $\mathrm{Cl}^{-}$removal decreased rapidly with the increase of the solution's temperature. Because the stable existence temperature of $\mathrm{Ca}_{4} \mathrm{Al}_{2} \mathrm{Cl}_{2}(\mathrm{OH})_{12}$ is $40^{\circ} \mathrm{C}$ [23], a partial $\mathrm{Ca}_{4} \mathrm{Al}_{2} \mathrm{Cl}_{2}(\mathrm{OH})_{12}$ will breakdown to form more stable solids such as $\mathrm{Ca}_{3} \mathrm{Al}_{2}(\mathrm{OH})_{12}$ when the solution's temperature is more than $40^{\circ} \mathrm{C}$. So, it is necessary to reduce the wastewater temperature in practical engineering applications to achieve a higher $\mathrm{Cl}^{-}$removal.

3.4. Effect of Reaction Time. The effect of reaction time on $\mathrm{Cl}^{-}$removal is shown in Figure 6. Results show that the reaction time has a certain effect on $\mathrm{Cl}^{-}$removal. The $\mathrm{NOx}$

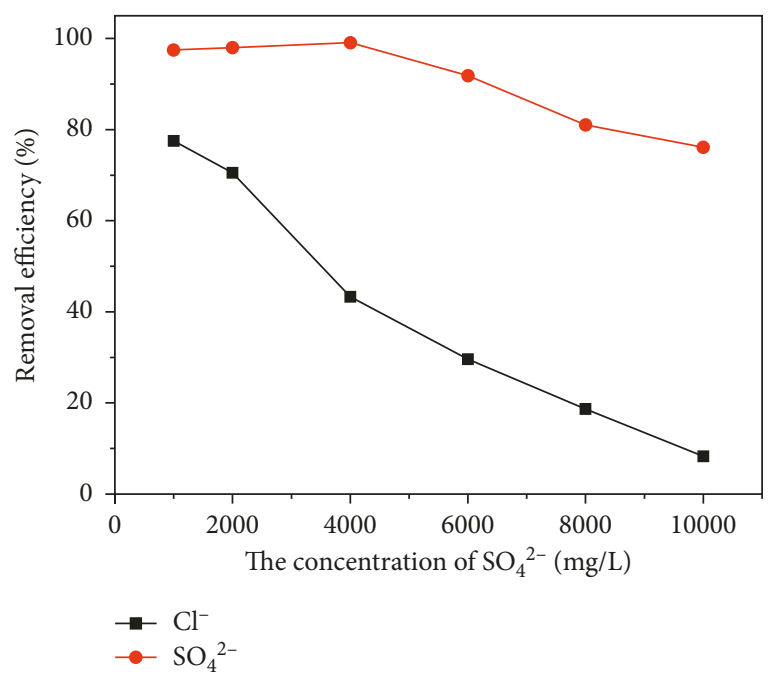

FIgURE 8: The effect of $\mathrm{SO}_{4}{ }^{2-}$ concentration.

removal sharply increased from $75.1 \%$ to $87.9 \%$ with the increase of reaction time from $10 \mathrm{~min}$ to $30 \mathrm{~min}$ and thereafter remained almost constant at about $88 \%-89 \%$. The contact time of ions in the solution increased, resulting in a more complete reaction and an increase of $\mathrm{Cl}^{-}$removal; however, limited by the low solubility of $\mathrm{Ca}(\mathrm{OH})_{2}$, the increase of contact time had a little effect on $\mathrm{Cl}^{-}$removal. Taking into account the economic factor and $\mathrm{Cl}^{-}$removal, the optimum reaction time is selected as $30 \mathrm{~min}$.

3.5. Effect of Stirring Speed. Stirring speed has a significant effect on $\mathrm{Cl}^{-}$removal. As shown in Figure 7, when stirring speed increased from $100 \mathrm{r} / \mathrm{min}$ to $200 \mathrm{r} / \mathrm{min}, \mathrm{Cl}^{-}$removal sharply increased from $62.7 \%$ to $82.7 \%$ and then gradually increased. When the stirring speed was more than $400 \mathrm{r} / \mathrm{min}$, the $\mathrm{Cl}^{-}$removal was little affected by the stirring speed and maintained between $89 \%$ and $91 \%$. Increasing the stirring speed contributes to the dispersion and dissolution of the reagents and increases the probability of collision of various ions in the solution, resulting in higher $\mathrm{Cl}^{-}$removal. However, excessive stirring speed not only cannot significantly improve the $\mathrm{Cl}^{-}$removal, but also leads to increased operating costs, so the optimum stirring speed is selected as $400 \mathrm{r} / \mathrm{min}$.

3.6. Effect of Anions. Various types of anions such as $\mathrm{SO}_{4}{ }^{2-}$, $\mathrm{NO}_{3}{ }^{-}$, and $\mathrm{F}^{-}$exist in the DDW and DW, and the concentrations of these anions are often high. So, coexistent anions in the solution have a certain effect on $\mathrm{Cl}^{-}$removal. In this paper, the effect of anions on $\mathrm{Cl}^{-}$removal has been studied, and the results are shown in Figures 8-10.

Figure 8 displays the effect of $\mathrm{SO}_{4}{ }^{2-}$ concentration on $\mathrm{Cl}^{-}$ removal. As Figure 8 illustrates, $\mathrm{SO}_{4}{ }^{2-}$ concentration has a significant effect on $\mathrm{Cl}^{-}$removal. $\mathrm{Cl}^{-}$removal sharply decreased from $77.5 \%$ to $8.3 \%$ when $\mathrm{SO}_{4}{ }^{2-}$ concentration increased from $1000 \mathrm{mg} / \mathrm{L}$ to $10000 \mathrm{mg} / \mathrm{L}$. Compared with the low $\mathrm{Cl}^{-}$removal, $\mathrm{SO}_{4}{ }^{2-}$ removal almost remained stable at more than $97 \%$ when $\mathrm{SO}_{4}{ }^{2-}$ concentration varied from 
TABLE 2: Results of $\mathrm{Cl}^{-}$and $\mathrm{SO}_{4}{ }^{2-}$ removal.

\begin{tabular}{lccccc}
\hline & & Number & Average & Standard deviation \\
\hline Average removal efficiencies of $\mathrm{Cl}^{-}(\%)$ & 1 & 2 & 3 & 86.49 & 0.138 \\
Average removal efficiencies of $\mathrm{SO}_{4}{ }^{2-}(\%)$ & 99.06 & 99.10 & 98.60 & 98.92 & 0.278 \\
\hline
\end{tabular}

Two-stage Freund's salt precipitation method. (1) The first stage mainly removed $\mathrm{SO}_{4}{ }^{2-}(4000 \mathrm{mg} / \mathrm{L})$, the molar ratio of $\mathrm{Ca}(\mathrm{OH})_{2}$ to $\mathrm{NaAlO}_{2}$ to $\mathrm{SO}_{4}{ }^{2-}$ was constant at $4: 1: 1$; the solution's temperature was $25^{\circ} \mathrm{C}$, reaction time was $30 \mathrm{~min}$, and the stirring speed was $400 \mathrm{r} / \mathrm{min}$. (2) The second stage mainly removed Cl${ }^{-}(2000 \mathrm{mg} / \mathrm{L}$ ), the molar ratio of $\mathrm{Ca}(\mathrm{OH})_{2}$ to $\mathrm{NaAlO}_{2}$ to $\mathrm{Cl}^{-}$was constant at $6: 3: 1$, respectively, and other operating conditions were the same as the first stage.

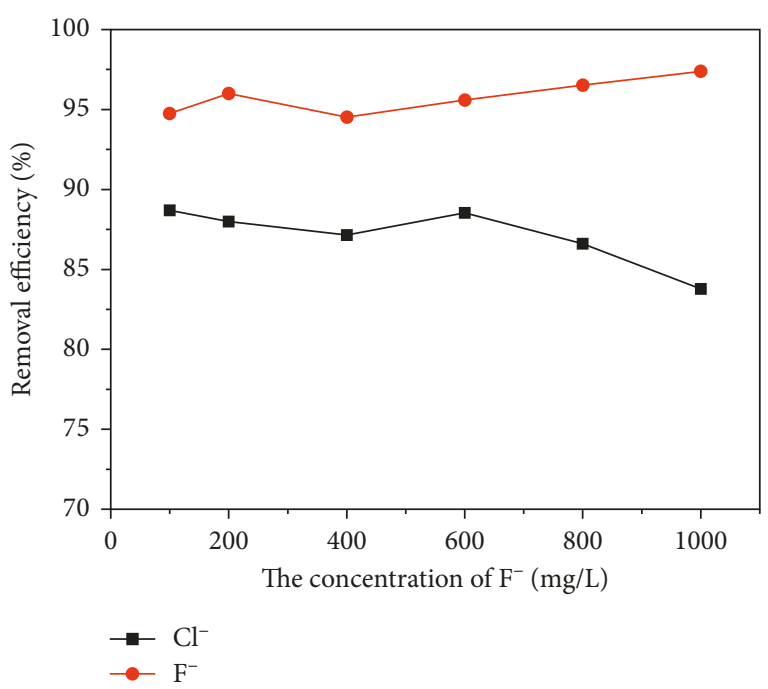

FIGURE 9: The effect of $\mathrm{F}^{-}$concentration.

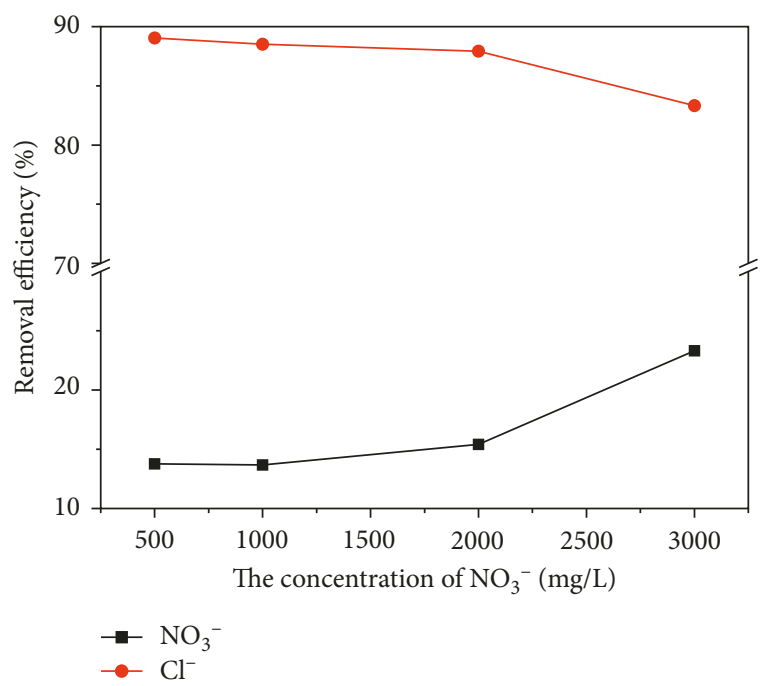

FIgURE 10: The effect of $\mathrm{NO}_{3}{ }^{-}$concentration.

$1000 \mathrm{mg} / \mathrm{L}$ to $4000 \mathrm{mg} / \mathrm{L}$, then slowly decreased with the increase of $\mathrm{SO}_{4}{ }^{2-}$ concentration. It has been reported that $\mathrm{SO}_{4}{ }^{2-}$ can react with $\mathrm{Ca}^{2+}$ and $\mathrm{Al}^{3+}$ to form insoluble ettringite $\left(\mathrm{Ca}_{6} \mathrm{Al}_{2}\left(\mathrm{SO}_{4}\right)_{3}(\mathrm{OH})_{12}\right)$. The solubility products of $\mathrm{Ca}_{6} \mathrm{Al}_{2}\left(\mathrm{SO}_{4}\right)_{3}(\mathrm{OH})_{12}$ and $\mathrm{Ca}_{4} \mathrm{Al}_{2} \mathrm{Cl}_{2}(\mathrm{OH})_{12}$ are about $10^{-109.9}$ and $10^{-27.10}$, respectively $[10,22]$. So, $\mathrm{Ca}^{2+}$ and $\mathrm{Al}^{3+}$ in the solution are easier to react with $\mathrm{SO}_{4}{ }^{2-}$ rather than $\mathrm{Cl}^{-}$, leading to higher $\mathrm{SO}_{4}{ }^{2-}$ removal and lower $\mathrm{Cl}^{-}$removal.
Results show that the presence of $\mathrm{SO}_{4}{ }^{2-}$ in the solution has a significant inhibitory effect on $\mathrm{Cl}^{-}$removal. In order to achieve high $\mathrm{Cl}^{-}$removal, it is necessary to remove the $\mathrm{SO}_{4}{ }^{2-}$ from the solution first. Table 2 shows the results of $\mathrm{SO}_{4}{ }^{2-}$ and $\mathrm{Cl}^{-}$removal using two-stage Friedel's salt precipitation method, the average removal efficiencies of $\mathrm{SO}_{4}{ }^{2-}$ and $\mathrm{Cl}^{-}$ can reach $98.9 \%$ and $86.2 \%$, respectively.

Figure 9 shows that $\mathrm{Cl}^{-}$removal almost remained stable at about $88 \%$ when $\mathrm{F}^{-}$concentration increased from $100 \mathrm{mg} / \mathrm{L}$ to $600 \mathrm{mg} / \mathrm{L}$, then decreased slowly from $88.5 \%$ to $83.8 \%$ when $\mathrm{F}^{-}$concentration increased from $600 \mathrm{mg} / \mathrm{L}$ to $1000 \mathrm{mg} / \mathrm{L}$, meanwhile $\mathrm{F}^{-}$removal almost remained stable at the range of $94 \%$ to $98 \%$. Due to the large amount of $\mathrm{Ca}$ $(\mathrm{OH})_{2}$ dosage compared with the stoichiometric value, it is estimated that $\mathrm{Ca}^{2+}$ in the solution is excessive, so $\mathrm{F}^{-}$can react with $\mathrm{Ca}^{2+}$ to form insoluble $\mathrm{CaF}_{2}$ and not affect $\mathrm{Cl}^{-}$ removal when the $\mathrm{F}^{-}$concentration is low. However, the further increase of $\mathrm{F}^{-}$concentration causes competitive reactions of $\mathrm{F}^{-}$and $\mathrm{Cl}^{-}$for the $\mathrm{Ca}^{2+}$ and results in a decrease of $\mathrm{Cl}^{-}$removal.

The effect of $\mathrm{NO}_{3}{ }^{-}$concentration on $\mathrm{Cl}^{-}$removal is shown in Figure 10. The results indicate that the $\mathrm{Cl}^{-}$removal was little affected when the concentration of $\mathrm{NO}_{3}{ }^{-}$in the solution was less than $2000 \mathrm{mg} / \mathrm{L}$, and remained stable at about $88 \%$; meanwhile, about $15 \%$ of $\mathrm{NO}_{3}{ }^{-}$removal was achieved. When the concentration of $\mathrm{NO}_{3}{ }^{-}$in the solution increased from $2000 \mathrm{mg} / \mathrm{L}$ to $3000 \mathrm{mg} / \mathrm{L}$, the $\mathrm{Cl}^{-}$removal slowly decreased from $87.9 \%$ to $83.3 \%$, and the $\mathrm{NO}_{3}{ }^{-}$removal slowly increased from $15.4 \%$ to $23.3 \%$. $\mathrm{NO}_{3}{ }^{-}$can react with $\mathrm{Ca}^{2+}$ and $\mathrm{Al}^{3+}$ to form the $\mathrm{Ca}_{4} \mathrm{Al}_{2}\left(\mathrm{NO}_{3}\right)_{2}(\mathrm{OH})_{12}$ that belong to AFm family of solids [24]; therefore, there is a certain negative impact on the $\mathrm{Cl}^{-}$removal. Overall, $\mathrm{NO}_{3}{ }^{-}$ has a certain inhibitory effect on $\mathrm{Cl}^{-}$removal only under high $\mathrm{NO}_{3}{ }^{-}$concentration.

3.7. Determination of the Optimal Experimental Conditions. The results indicate that using Friedel's salt precipitation method can effectively remove $\mathrm{Cl}^{-}$in the solution. $\mathrm{Cl}^{-}$removal depends primarily on the $\mathrm{Ca}(\mathrm{OH})_{2}$ dosage, $\mathrm{NaAlO}_{2}$ dosage, the solution's temperature, and $\mathrm{SO}_{4}{ }^{2-}$ concentration, and the solution's initial $\mathrm{pH}$, reaction time, stirring speed, $\mathrm{NO}_{3}{ }^{-}$, and $\mathrm{F}^{-}$concentrations all have a certain influence on NOx removal, but these factors have a relatively little influence on the $\mathrm{Cl}^{-}$removal. Finally, considering the application to the practical engineering, the optimal conditions for $\mathrm{Cl}^{-}$removal using Friedel's salt precipitation method were identified: (1) For sulfate-free wastewater, use one-stage Freund's salt precipitation method to remove $\mathrm{Cl}^{-}$. 


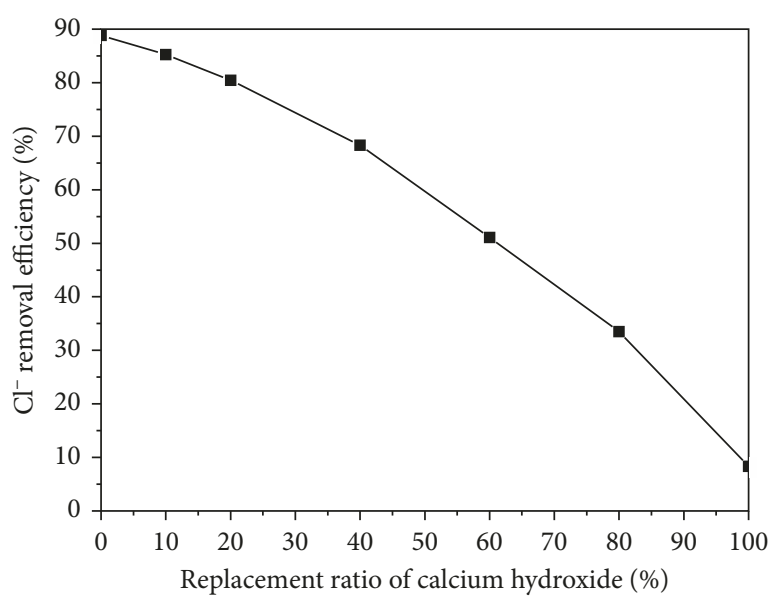

FIgURE 11: The effect of precipitated solid reuse.

TABLE 3: Results of anion removal.

\begin{tabular}{lccccc}
\hline & $\mathrm{SO}_{4}{ }^{2-}$ & $\mathrm{Cl}^{-}$ & $\mathrm{F}^{-}$ & $\mathrm{NO}_{3}^{-}$ & $\mathrm{pH}$ \\
\hline $\begin{array}{l}\text { Actual wastewater }(\mathrm{mg} / \mathrm{L}) \\
\begin{array}{l}\text { Purified wastewater } \\
(\mathrm{mg} / \mathrm{L})\end{array}\end{array}$ & 12309.5 & 1476.7 & 244.9 & 955.3 & 5.3 \\
$\begin{array}{l}\text { Average removal efficiency } \\
(\%)\end{array}$ & 98.47 & 85.43 & 96.39 & 17.23 & - \\
\hline
\end{tabular}

The optimal conditions were the molar ratio of $\mathrm{Ca}(\mathrm{OH})_{2}$ to $\mathrm{NaAlO}_{2}$ to $\mathrm{Cl}^{-} 6: 3: 1$, solution's temperature of $25^{\circ} \mathrm{C}$, reaction time of $30 \mathrm{~min}$, and stirring speed of $400 \mathrm{r} / \mathrm{min}$. (2) For sulfate-containing wastewater, use two-stage Freund's salt precipitation method to remove $\mathrm{Cl}^{-}$. First stage mainly removed $\mathrm{SO}_{4}{ }^{2-}$, the optimal conditions were the molar ratio of $\mathrm{Ca}(\mathrm{OH})_{2}$ to $\mathrm{NaAlO}_{2}$ to $\mathrm{SO}_{4}{ }^{2-} 4: 1: 1$, solution's temperature of $25^{\circ} \mathrm{C}$, reaction time of $30 \mathrm{~min}$ and stirring speed of $400 \mathrm{r} / \mathrm{min}$. Second stage mainly removed $\mathrm{Cl}^{-}$, and the optimal conditions were the same as those used for sulfatefree wastewater.

3.8. Effect of Precipitated Solid Reuse. The XRD test (Figure 3) of the precipitated solids indicated that there existed a certain amount of $\mathrm{Ca}(\mathrm{OH})_{2}$ in the precipitated solids, so it is possible to replace part of $\mathrm{Ca}(\mathrm{OH})_{2}$ with the precipitated solids. As shown in Figure 11, $\mathrm{Cl}^{-}$removal rapidly decreased with the increase of replacement ratio of $\mathrm{Ca}(\mathrm{OH})_{2}$, the main reason is that the $\mathrm{Ca}(\mathrm{OH})_{2}$ content of the precipitated solids was low, so it can't be achieved to use precipitated solids to replace an equivalent number of $\mathrm{Ca}(\mathrm{OH})_{2}$. However, $\mathrm{Cl}^{-}$ removal can reach more than $80 \%$ when the replacement ratio of $\mathrm{Ca}(\mathrm{OH})_{2}$ is controlled at less than $20 \%$.

3.9. Removal of Chloride Ion and Other Ions in Actual DDW. Removal of $\mathrm{Cl}^{-}$and other ions in actual wastewater by using Friedel's salt precipitation method was studied. The wastewater was the actual DDW from a ceramic plant. The $\mathrm{NaClO}_{2} / \mathrm{NaOH}$ solution was used to remove the $\mathrm{NOx}$ and $\mathrm{SO}_{2}$ in the flue gas, and the wet flue gas desulfurization and denitrification system was operated under weak acid condition.
TABLE 4: Results of heavy metal ion removal.

\begin{tabular}{lccccc}
\hline & $\mathrm{Cd}^{2+}$ & $\mathrm{Mg}^{2+}$ & $\mathrm{Mn}^{2+}$ & $\mathrm{Ni}^{2+}$ & $\mathrm{Pb}^{2+}$ \\
\hline $\begin{array}{l}\text { Actual wastewater (mg/L) } \\
\text { Purified wastewater (mg/L) }\end{array}$ & 4.332 & 10.88 & 23.85 & 37.62 & 9.20 \\
$\begin{array}{l}\text { Average removal } \\
\text { efficiency (\%) }\end{array}$ & 100 & 99.21 & 99.97 & 100 & 100 \\
\hline
\end{tabular}

So, the effluent from the system contained large amounts of $\mathrm{Cl}^{-}$and other ions (Tables 2 and 3). Two-stage Friedel's salt precipitation method was used to purify the anion ions and other ions, and the results are shown in Tables 3 and 4. The results indicate that Friedel's salt precipitation method had high synergistic removal efficiencies for $\mathrm{Cl}^{-}, \mathrm{SO}_{4}{ }^{2-}, \mathrm{F}^{-}$, and heavy metal ions, with average removal efficiencies of $85.43 \%, 98.47 \%, 96.39 \%$, and more than $99 \%$, respectively. The $\mathrm{Cl}^{-}$concentration in the purified wastewater met the requirements for reuse of water which is $250 \mathrm{mg} / \mathrm{L}$ in China; meanwhile, $\mathrm{SO}_{4}{ }^{2-}, \mathrm{F}^{-}$, and heavy metal ions were effectively removed. So the purified wastewater could be reused in the wet flue gas desulfurization and denitrification system. In addition, the $\mathrm{pH}$ of the purified water was about 13 , so purified wastewater reuse could reduce the consumption of alkali in the flue gas treatment system.

\section{Conclusions}

In this study, Friedel's salt precipitation method was used to remove the $\mathrm{Cl}^{-}$, and the effects of different experimental conditions on $\mathrm{Cl}^{-}$removal were mainly studied. Based on the results of the experiments, the following conclusions can be made:

(1) Friedel's salt precipitation method is a very effective $\mathrm{Cl}^{-}$removal technology, and $\mathrm{Cl}^{-}$removal can reach more than $85 \%$. Meanwhile, the method can effectively synergistically remove $\mathrm{SO}_{4}{ }^{2-}, \mathrm{F}^{-}$, and heavy metal ions. The purified wastewater can be reused to reduce the consumption of water and alkali, and the precipitated solids can be used to replace part of $\mathrm{Ca}$ $(\mathrm{OH})_{2}$. Thus, it has a great potential to be applied in the industrial wastewater treatment field.

(2) $\mathrm{Ca}(\mathrm{OH})_{2}$ dosage, $\mathrm{NaAlO}_{2}$ dosage, the solution's initial $\mathrm{pH}$, the solution's temperature, reaction time, stirring speed, and anions $\left(\mathrm{SO}_{4}{ }^{2-}, \mathrm{NO}_{3}{ }^{-}\right.$and $\left.\mathrm{F}^{-}\right)$have all effects on the $\mathrm{Cl}^{-}$removal. Finally, considering the application to the practical engineering, the optimal conditions for $\mathrm{Cl}^{-}$removal using Friedel's salt precipitation method were determined.

(3) The removal mechanism of $\mathrm{Cl}^{-}$was deduced based on the experimental results, composition of the precipitated solids, and the literatures. The results showed that $\mathrm{Cl}^{-}$can be removed by precipitation as $\mathrm{Ca}_{4} \mathrm{Al}_{2} \mathrm{Cl}_{2}(\mathrm{OH})_{12}$.

\section{Data Availability}

The data used to support the findings of this study are available from the corresponding author upon request. 


\section{Conflicts of Interest}

The authors declare that they have no competing interests.

\section{Acknowledgments}

This work was supported by the National Key R\&D Program of China (2017YFC0210704, 2017YFC0210803), the National Natural Science Foundation of China (NSFC-51778264), the Natural Science Foundation of Guangdong Province (2015A030310344), the Project of Science and Technology Program of Guangdong Province (2015A020220008, 2015B020215008, 2016B020241002, and 2017B020237002), the Youth Top-notch Talent Special Support Program of Guangdong Province (2016TQ03Z576), and the Pearl River S\&T Nova Program of Guangzhou (201610010150).

\section{References}

[1] R. T. Huang, L. Y. Luo, X. C. Zhou et al., "Aerosol formation by heterogeneous reactions in ammonia-based WFGD systems," Journal of Aerosol Science, vol. 114, pp. 1-12, 2017.

[2] Z. H. Wang, J. H. Zhou, Y. Q. Zhu et al., "Simultaneous removal of $\mathrm{NOx}, \mathrm{SO}_{2}$ and $\mathrm{Hg}$ in nitrogen flow in a narrow reactor by ozone injection: experimental results," Fuel Processing Technology, vol. 88, no. 8, pp. 817-823, 2007.

[3] D. S. Jin, B. R. Deshwal, Y. S. Park et al., "Simultaneous removal of $\mathrm{SO}_{2}$ and $\mathrm{NO}$ by wet scrubbing using aqueous chlorine dioxide solution," Journal of Hazardous Materials, vol. 135, no. 1-3, pp. 412-417, 2006.

[4] X. H. Xu, Q. F. Ye, T. M. Tang et al., "Hg0 oxidative absorption by $\mathrm{K}_{2} \mathrm{~S}_{2} \mathrm{O}_{8}$ solution catalyzed by $\mathrm{Ag}^{+}$and $\mathrm{Cu}^{2+}$," Journal of Hazardous Materials, vol. 158, pp. 410-416, 2008.

[5] P. Fang, C. P. Cen, X. M. Wang et al., "Simultaneous removal of $\mathrm{SO}_{2}, \mathrm{NO}$ and $\mathrm{HgO}$ by wet scrubbing using urea $+\mathrm{KMnO}_{4}$ solution," Fuel Processing Technology, vol. 106, pp. 645-653, 2013.

[6] R. L. Hao, Y. Y. Zhang, Z. Y. Wang et al., "An advanced wet method for simultaneous removal of $\mathrm{SO}_{2}$ and NO from coalfired flue gas by utilizing a complex absorbent," Chemical Engineering Journal, vol. 307, pp. 562-571, 2017.

[7] P. Fang, Z. J. Tang, X. B. Chen et al., "Split, partial oxidation and mixed absorption: a novel process for synergistic removal of multiple pollutants from simulated flue gas," Industrial and Engineering Chemistry Research, vol. 56, no. 17, pp. 51165126, 2017.

[8] Y. X. Liu, J. Zhang, C. D. Sheng, Y. Zhang, and L. Zhao, "Simultaneous removal of $\mathrm{NO}$ and $\mathrm{SO}_{2}$ from coal-fired flue gas by $\mathrm{UV} / \mathrm{H}_{2} \mathrm{O}_{2}$ advanced oxidation process," Chemical Engineering Journal, vol. 162, no. 3, pp. 1006-1011, 2010.

[9] L. B. Niu and K. Nakada, "Effect of chloride and sulfate ions in simulated boiler water on pitting corrosion behavior of $13 \mathrm{Cr}$ steel," Corrosion Science, vol. 96, pp. 171-177, 2015.

[10] A. Abdel-Wahab and B. Batchelor, "Chloride removal from recycled cooling water using ultra-high lime with aluminum process," Water Environment Research, vol. 74, no. 3, pp. 256263, 2002.

[11] L. Cui, G. P. Li, Y. Z. Li et al., "Electrolysis-electrodialysis process for removing chloride ion in wet flue gas desulfurization wastewater (DW): influencing factors and energy consumption analysis," Chemical Engineering Research and Design, vol. 123, pp. 240-247, 2017.
[12] W. A. Shaw, "Fundamentals of zero liquid discharge system design," Power, vol. 155, pp. 56-63, 2011.

[13] X. L. Wu, Z. Q. Liu, and X. Liu, "Chloride ion removal from Zinc sulfate aqueous solution by electrochemical method," Hydrometallurgy, vol. 134-135, pp. 62-65, 2013.

[14] B. Elsener and U. Angst, "Mechanism of electrochemical chloride removal," Corrosion Science, vol. 49, no. 12, pp. 4504-4522, 2007.

[15] Y. Zhou, D. S. Hou, J. Y. Jiang, L. Liu, W. She, and J. Yu, "Experimental and molecular dynamics studies on the transport and adsorption of chloride ions in the nano-pores of calcium silicate phase: the influence of calcium to silicate ratios," Microporous and Mesoporous Materials, vol. 255, pp. 23-35, 2018.

[16] E. Iakovleva, E. Makila, J. Salonen et al., "Industrial products and wastes as adsorbents for sulphate and chloride removal from synthetic alkaline solution and mine process water," Chemical Engineering Journal, vol. 259, pp. 364-371, 2015.

[17] L. Lv, P. D. Sun, Z. Y. Gu et al., "Removal of chloride ion from aqueous solution by $\mathrm{ZnAl}-\mathrm{NO}_{3}$ layered double hydroxides as anion-exchanger," Journal of Hazardous Materials, vol. 161, no. 2-3, pp. 1444-1449, 2009.

[18] H. S. Li, Y. H. Chen, J. Y. Long et al., "Simultaneous removal of thallium and chloride from a highly saline industrial wastewater using modified anion exchange resins," Journal of Hazardous Materials, vol. 333, pp. 179-185, 2017.

[19] S. X. Jiang, Y. N. Li, and P. L. Bradley, "A review of reverse osmosis membrane fouling and control strategies," Science of the Total Environment, vol. 595, pp. 567-583, 2017.

[20] H. H. Chen, L. R. Yuan, M. X. Li et al., "Research progress in technology of chloride removal from aqueous solution," Journal of Materials Protection, vol. 48, pp. 31-35, 2015, in Chinese.

[21] G. L. Chen, C. L. Fu, and G. M. Fu, "Dechlorination test using $\mathrm{Cu}$-bearing byproduct from oxygen pressure acid leaching," China Nonferrous Metallurgy, vol. 6, pp. 29-31, 2016, in Chinese.

[22] A. Abdel-Wahab, B. Batchelor, and J. Schwantes, "An equilibrium model for chloride removal from recycled cooling water using the ultra-high lime with aluminum process," Water Environment Research, vol. 77, no. 7, pp. 3059-3065, 2005.

[23] Z. L. Cheng, B. J. Yang, H. W. Tang et al., "Experimental research on chloride removal from water by ultra-high lime with aluminum process," Industrial Water Treatment, vol. 35, pp. 38-41, 2015, in Chinese.

[24] J. P. Rapin, G. Renaudin, E. Elkaim, and M. Francois, "Structural transition of Friedel's salt $3 \mathrm{CaO} \cdot \mathrm{Al}_{2} \mathrm{O}_{3} \cdot \mathrm{CaCl}_{2} \cdot 10 \mathrm{H}_{2} \mathrm{O}$ studied by synchrotron powder diffraction," Cement and Concrete Research, vol. 32, no. 4, pp. 513-519, 2002. 

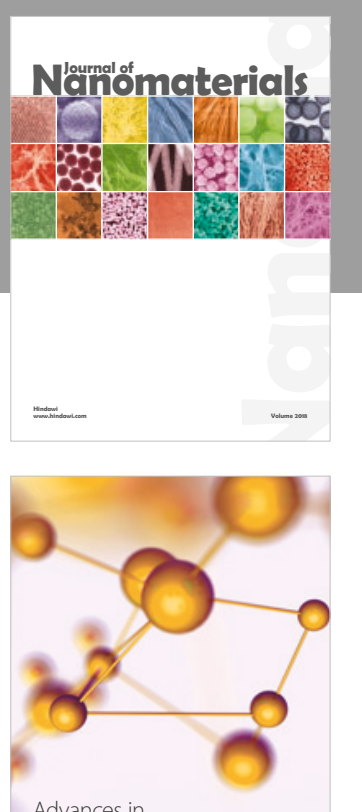

Physical Chemistry
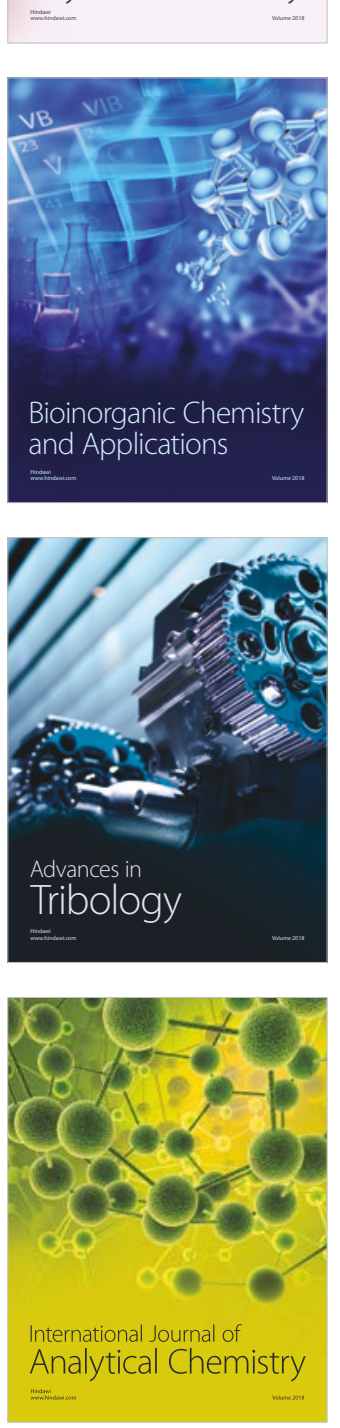

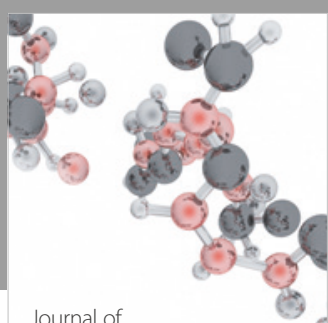

Analytical Methods

in Chemistry

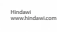

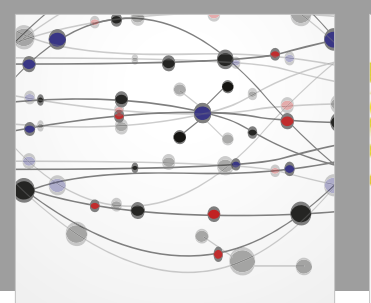

The Scientific World Journal

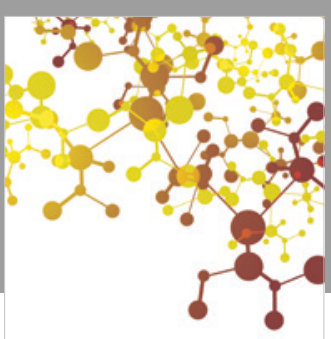

Journal of

Applied Chemistry
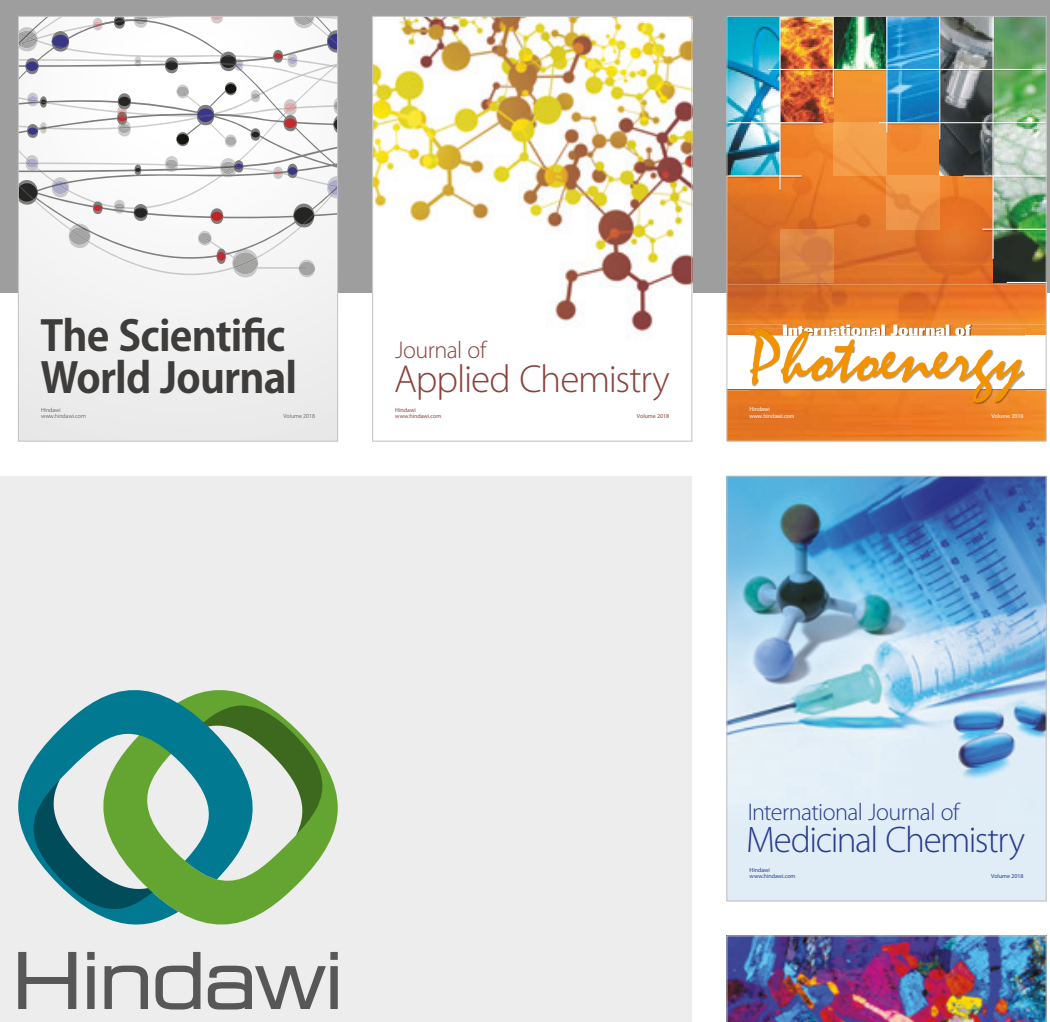

Submit your manuscripts at

www.hindawi.com
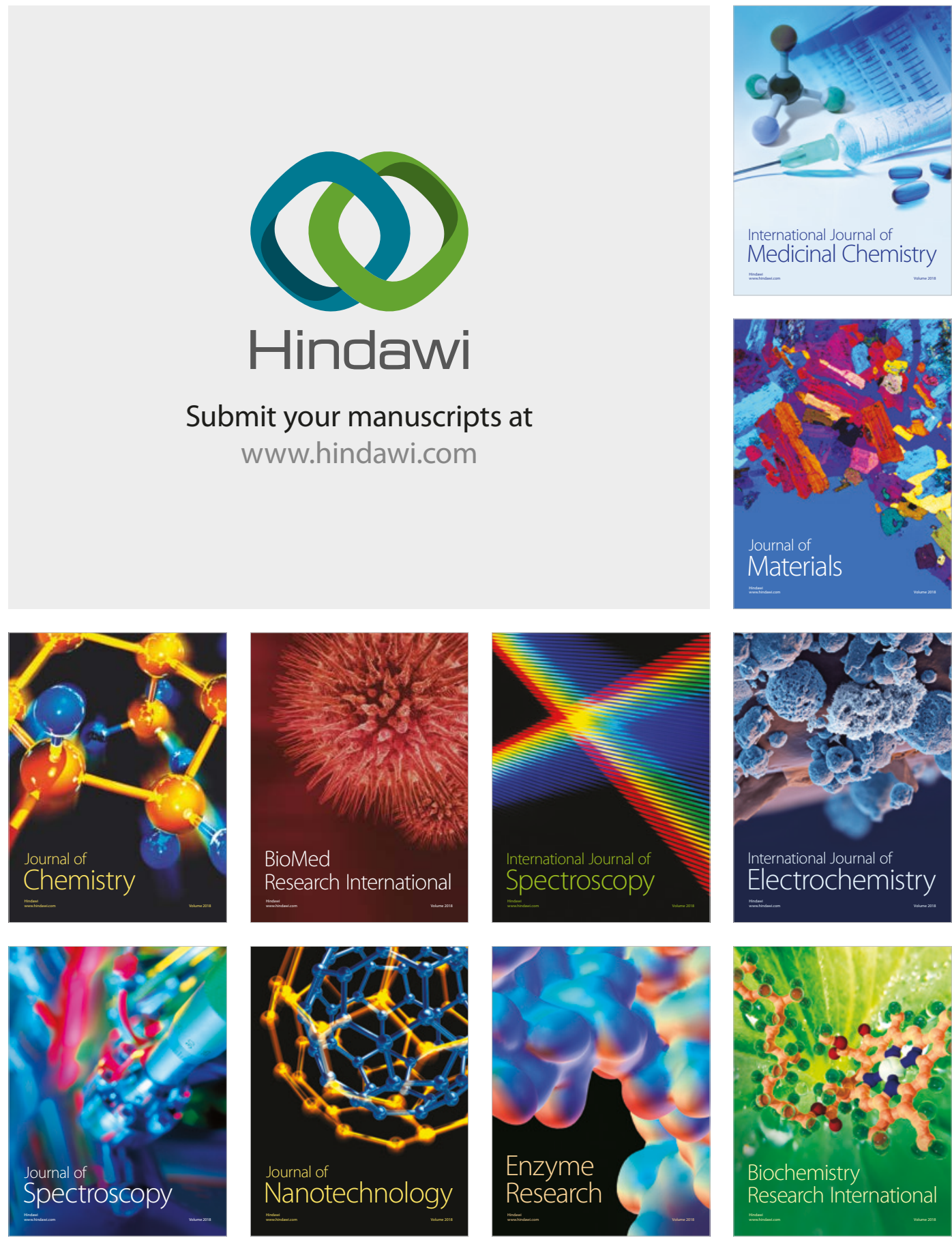
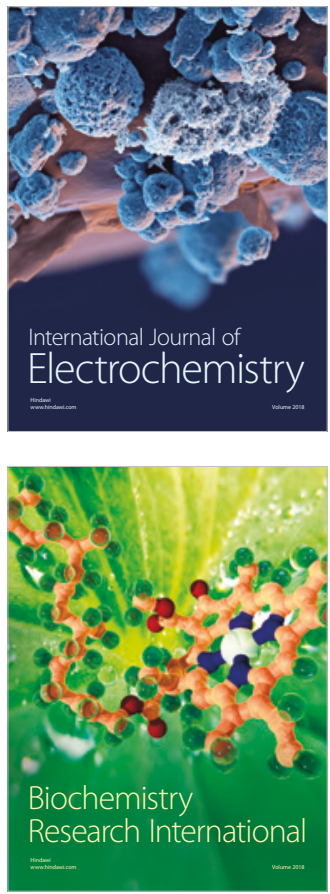